\title{
THE SEARCH OF COMPOUNDS WITH ANTIAGGREGATION ACTIVITY AMONG S-ESTERS OF THIOSULFONIC ACIDS
}

\author{
T. I. HALENOVA', I. V. NIKOLAEVA', A. V. NAKONECHNA', \\ K. B. BOLIBRUKH ${ }^{2}$, N. Y. MONKA ${ }^{2}$, V. I. LUBENETS ${ }^{2}$, \\ O. M. SAVCHUK ${ }^{1}$, V. P. NOVIKOV ${ }^{2}$, L. I. OSTAPCHENKO ${ }^{1}$ \\ ${ }^{1}$ Educational and Scientific Centre "Institute of Biology", \\ Taras Shevchenko National University of Kyiv, Ukraine; \\ ${ }^{2}$ Lviv Polytechnic National University, Ukraine; \\ e-mail: galenovatanya@rambler.ru
}

According to the current understanding, the hyperactivation of platelets may lead to increased intravascular coagulation and thrombosis. Today a relevant issue is the search for new anti-thrombotic agents that are able to modulate the activity of platelet receptors, thus, influence the processes of activation and aggregation of platelets. The aim of this study was to investigate the effects of newly synthesized thiosulfonate derivatives on platelet aggregation. The activity of the compounds was tested in vitro using platelet-rich plasma. As a result of the screening test, structural formulas of four agents with high antiaggregative activity were established. These compounds inhibited ADP- and collagen-induced platelet aggregation in a dosedependent manner. Two of these compounds were shown to be more effective inhibitors of aggregation induced by $A D P\left(I C_{50} \sim 8-10 \mu M\right)$, as well as collagen $\left(I C_{50} \sim 1.5-2.0 \mu M\right)$.

Key words: platelets, aggregation, thiosulfonic acid derivatives, ADP-receptor antagonists, antithrombotic agents.

$\mathrm{N}$

owadays, thrombotic vascular diseases remain one of the most important problems of modern medicine and pharmacy. Relevance of this problem is caused, on the one hand, by their prevalence, and on the other hand, by thrombosis complications leading to disability and mortality in patients [1]. Thrombosis is the pathological process characterized by abnormal thrombus formation in blood vessels and the result of complex interactions of various etiological factors and pathogenetic mechanisms [2, 3]. A common cause of excessive thrombus formation is hyperactivation of the platelet stage of the hemostasis process [4].

Platelets, due to their adhesive and aggregation functions, are extremely important elements, not only of the normal process of hemostasis [5], but also the process of pathological thrombus formation [6, 7]. Platelet membrane contains numerous receptors, which help to transfer a signal from the inducer (ADP, collagen, von Willebrand factor, etc.) to intracellular messengers, which facilitate cellular activation, secretion of prothrombotic mediators by platelets, as well as the aggregation process [5]. Therefore, current points of interest are to study mechanisms of regulation of platelet receptors functioning and the search for new agents that may affect their activity and thus, the process of thrombus formation [8]. However, the numerous clinical studies have shown that the application of modern anti-platelet drugs are often accompanied by side effects such as resistance to their action, an increased risk of uncontrolled bleeding or the development of serious systemic complications that along with the high costs of these medications suggests the need for further search for new, more efficient and safer antiplatelet drugs.

Various sulfur-containing organic compounds have a particular importance in such researches. Among these compounds, S-esters of thiosulfonic acids are reported to be valued sulfonating agents and have a wide range as well as a high level of biological activities [9-11]. Thiosulfoesters are the close structural analogues of phytoncides of garlic (Allium sativum L.), onion (Allium cepa L.) [10]. It has recently been found that cauliflower and some sea-urchins such as Echinocardium cordatum are the natural sources of thiosulfonic compounds [12]. The synthesis of structural analogues of natural bio- 
logically active compounds, in particular S-esters of thiosulfonic acids, and study of their biological activities can be the basis for development of novel and effective therapeutic substances for various purposes.

The aim of this work was to conduct primary screening of S-esters of thiosulfonic acids for antiaggregation activity in vitro.

\section{Materials and Methods}

The test compounds were synthesized in the Department of Technology of Biologically Active Substances, Pharmacy and Biotechnology of the Lviv Polytechnic National University [13, 14]. To dissolve the substances, dimethyl sulfoxide (DMSO) (100\%) was used, while their test concentrations were prepared using distilled water. The final DMSO concentration in all experiments was constant at $1 \%$. It is known that DMSO may affect platelet functioning [15]. Test DMSO concentration was determined experimentally and defined as one that did not affect the degree of ADP- and collagen-dependent platelet aggregation, and was acceptable for further researches.

Blood from rabbit ear artery was collected into a polyethylene tube with $3.8 \%$ sodium citrate in ratio 9:1. Platelet-rich plasma (PRP) was obtained by centrifugation of stabilized blood at $300 \mathrm{~g}$ for $10 \mathrm{~min}$ at $20^{\circ} \mathrm{C}$. Platelet-poor plasma (PPP) was obtained by further centrifugation of PRP at $1500 \mathrm{~g}$ for $30 \mathrm{~min}$ at $20^{\circ} \mathrm{C}$.

Platelet aggregation was assessed within the first $3 \mathrm{~h}$ after blood sampling using photo-optical aggregometer AT-02 (Medtech, Russia). Before the assessment, the number of platelets in PRP was determined and, if necessary, PRP was diluted with PPP to concentration of 230-250 000 cells/ $\mu$ l. Aggregation analysis was performed according to the manufacturer instructions.

Primary screening for anti-aggregation activity of thiosulfonate derivatives was performed in vitro: PRP was incubated with studied compounds (final concentration was $50 \mu \mathrm{M}$ ) in a cuvette for $2 \mathrm{~min}$ at $37^{\circ} \mathrm{C}$ with constant stirring (500 rpm). PRP incubated with $1 \%$ DMSO was used as a control. As an aggregation inducer, we used ADP (Renam, Russia) at final concentration of $5 \times 10^{-6} \mathrm{M}$. In this experiment we studied the level of spontaneous aggregation induced by addition of the tested compounds to plasma, evaluated the degree of aggregation (the maximal level of light transmission of PRP after addition of inducer) and calculated the degree of inhibition of ADP-dependent aggregation under the action of thiosulfonic acid derivatives relative to control, which was taken as $100 \%$ (to ease result interpretations).

The $\mathrm{IC}_{50}$ value was determined for thiosulfoderivatives, which decreased the degree of ADP-dependent aggregation by more than $50 \%$ at concentration of $50 \mu \mathrm{M}$. For this, PRP was incubated with the studied compounds at concentration range from 1 to $100 \mu \mathrm{M}$ for 2 min followed by addition of inducers such as ADP $\left(5 \times 10^{-6} \mathrm{M}\right)$ or collagen $(2 \mathrm{mg} / \mathrm{ml})$. The $\mathrm{IC}_{50}$ value was defined as the concentration at which the compound inhibits platelet aggregation by $50 \%$.

The experiments studying the effect of thiosulfo-derivatives on platelet aggregation were performed on three PRP samples from different rabbits for each compound, in so doing, the experiment for each PRP sample was replicated three times. Statistical processing of the results was performed using software Statistica 7. Value changes were considered significant at $P<0.05$.

\section{Results and Discussion}

Based on the ability of ADP, one of the major physiological inducers, to cause platelet aggregation, medications such as ticlopidine, clopidogrel, etc. were developed, which are capable of inhibiting ADP receptors, thereby reducing the risk of thrombosis [16, 17]. It is known that some sulfur-containing organic compounds are effective inhibitors of platelet aggregation [9, 11, 18, 19].

Therefore, we have studied the effect of synthesized thiosulfonate derivatives on ADP-dependent platelet aggregation to find the potential antithrombotic agents among them.

The degree of aggregation in control PRP at 2 min incubation with $1 \%$ DMSO in response to introduction of $5 \times 10^{-6} \mathrm{M}$ ADP was $44 \pm 2 \%$. Aggregatogram under such conditions had a shape of reversal single-phase curve.

The obtained results on study of platelet antiaggregation activity of thiosulfonate derivatives are shown in Table. It was found that some test compounds exhibited inhibitory effect on ADPdependent aggregation. It should be noted that all synthesized thiosulfonate derivatives at the test concentration did not induce spontaneous platelet aggregation.

The obtained results showed that S-alkyl esters of alkanethiosulfoacids with unbranched aliphatic 
The structures and antiaggregation activities of esters and diesters of thiosulfonic acids

\begin{tabular}{|c|c|c|c|}
\hline \multirow[t]{2}{*}{$\mathrm{N}$} & \multicolumn{2}{|c|}{$\begin{array}{l}\text { Structure of derivatives with general formula } \\
\qquad \mathbf{R}^{1} \mathbf{S O}_{2} \mathbf{S R}^{2}\end{array}$} & \multirow{2}{*}{$\begin{array}{c}\text { Level of inhibition }(\%) \\
\text { relative to control }\end{array}$} \\
\hline & R1 & R2 & \\
\hline 1 & $\mathrm{H}_{3} \mathrm{C}-$ & $-\mathrm{CH}_{3}$ & $12 \pm 3$ \\
\hline 2 & $\mathrm{C}_{2} \mathrm{H}_{5^{-}}$ & $-\mathrm{CH}_{3}$ & $30 \pm 5^{*}$ \\
\hline 3 & $\mathrm{C}_{3} \mathrm{H}_{7^{-}}$ & $-\mathrm{CH}_{3}$ & No effect \\
\hline 4 & $\mathrm{H}_{3} \mathrm{C}-$ & $-\mathrm{CH}_{2} \mathrm{I}$ & No effect \\
\hline 5 & $\mathrm{H}_{3} \mathrm{C}-$ & $-\mathrm{CHI}_{2}$ & $70 \pm 6^{*}$ \\
\hline 6 & & $-\mathrm{CHI}_{2}$ & $17 \pm 3$ \\
\hline 7 & & $-\mathrm{CH}_{3}$ & $25 \pm 3 *$ \\
\hline 8 & & $-\mathrm{CH}_{3}$ & $35 \pm 4$ \\
\hline 9 & & $-\mathrm{C}_{2} \mathrm{H}_{5}$ & $8 \pm 2$ \\
\hline 10 & & $-\mathrm{C}_{3} \mathrm{H}_{5}$ & No effect \\
\hline 11 & & $-\mathrm{Na}$ & No effect \\
\hline 12 & & $-\mathrm{CH}_{3}$ & $15 \pm 2$ \\
\hline 13 & & $-\mathrm{C}_{2} \mathrm{H}_{5}$ & No effect \\
\hline 14 & & $-\mathrm{C}_{4} \mathrm{H}_{9}$ & No effect \\
\hline 15 & & $-\mathrm{Na}$ & No effect \\
\hline 16 & $\mathrm{H}_{3} \mathrm{C}-$ & & $100 \%$ \\
\hline 17 & & $-\mathrm{CH}_{3}$ & No effect \\
\hline 18 & & $-\mathrm{CH}_{3}$ & No effect \\
\hline 19 & & $-\mathrm{CH}_{3}$ & No effect \\
\hline
\end{tabular}




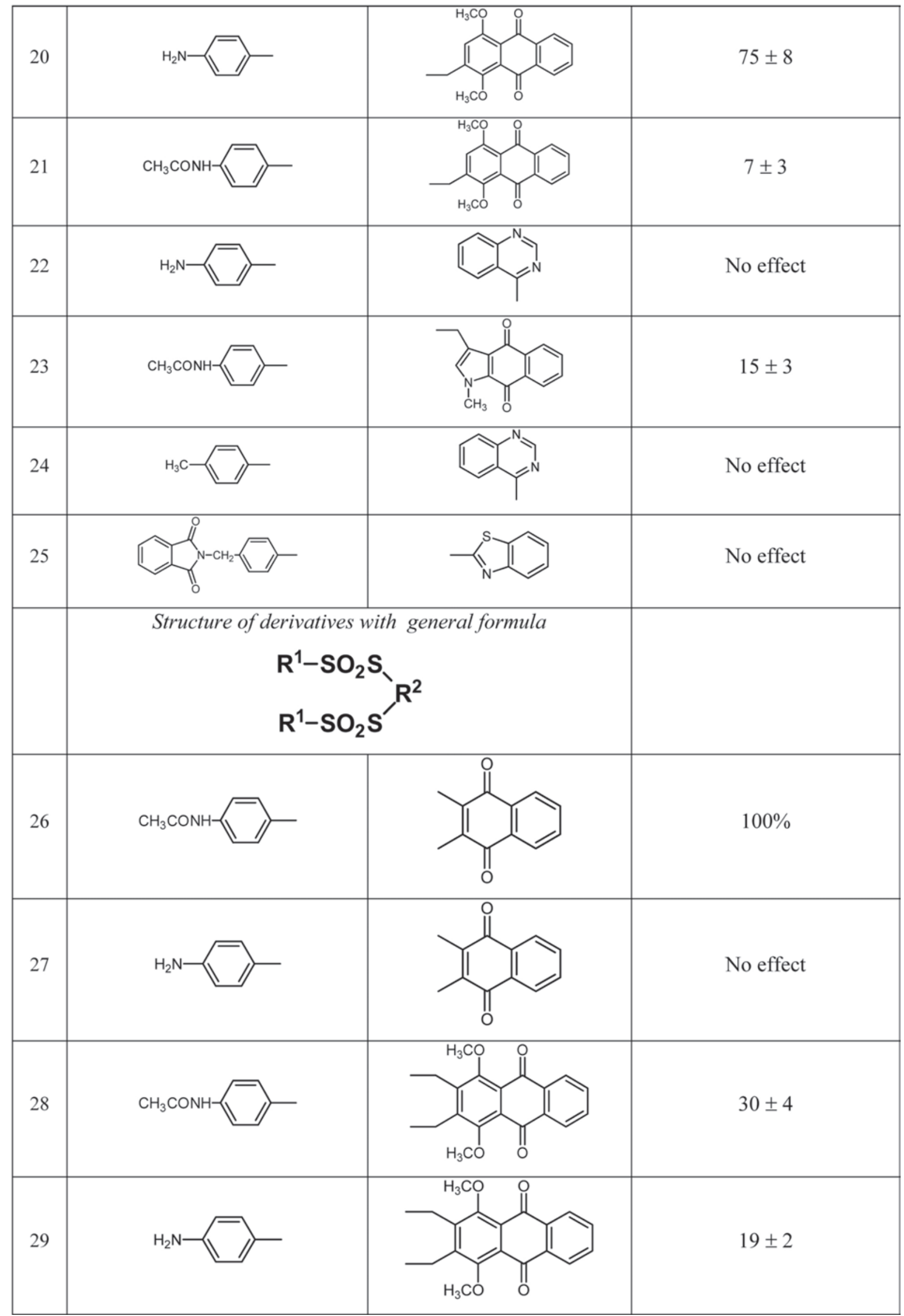




\begin{tabular}{|l|l|l|}
\hline 30 & No effect \\
\hline 32 & Structure of derivatives with general formula & No effect \\
\hline 33 & & No effect \\
\hline
\end{tabular}

radicals did not affect the level of ADP-dependent aggregation (compound 3), or exhibited low effect (compounds 1 and 2). Introduction of one halogen atom, in particular iodine, onto methyl thiol moiety of thiosulfonate (compound 4) did not affect antiaggregation activity, whereas diiodomethyl derivative (compound 5) exhibited a significant inhibitory effect on ADP-dependent aggregation. Modification of thiosulfonate 5, namely, replacement of the aliphatic substituent for the aromatic, in particular toluene, by sulfonyl moiety (compound 6) led to decreasing the inhibitory effect.

Inhibition of ADP-dependent platelet aggregation by $25 \%$ was observed at the action of S-methyl ester with the aromatic-benzene sulfonyl moiety (compound 7). Introduction of the amino group onto para-position of methyl ester benzenthiosulfoacid (compound 8) led to the increase of antiaggregation potential. However, the modification of radical R2 in the compound 8, namely, lengthening the carbon chain (compound 9); introduction of a double bond, in particular allyl fragment, onto it (compound 10); and the transition from ester to salt such as sodium 4-aminobenzenthiosulfonate (compound 11) led to a loss of the ability to inhibit ADP-dependent aggregation. Acylated structural analogues of compound 8 exhibited lower antiaggregation activity (compound 12) or absence of the ability to inhibit platelet aggregation (compounds 13, 14, 15).

One of the directions for the search of compounds having antiaggregation activity was to investigate the effect of compounds containing 1,4-naphthoquinone moiety. At incubation of PRP with S-(3-chloro-1,4-dioxo-1,4-dihydro-naphthalene-2-yl) methanthiosulfoacid ester (compound 16), platelet aggregation in response to addition of the inducer was not observed. This indicated $100 \%$ inhibition of ADP-dependent aggregation. Compounds 17, 18, 19 which are S-methyl esters of 4-phthalimidomethylbenzene-, 2-methoxycarbonylaminobenzimidazole-5- and 2-carbamoylaminobenzimidazole5-thiosulfonic acids, respectively, did not exhibit ability to inhibit ADP-dependent aggregation.

S-((1,4-dimethoxy-9,10-dioxo-9,10-dihydroanthracene-2yl)methyl) ester of 4-aminobenzenethiosulfoacid (compound 20) exhibited high anti-platelet activity. Acylation of amino group of this thiosulfoester (compound 21) as well as the substitution of 
thiol moiety for quinone fragment, namely (1-methyl-4,9-dioxo-4,9-dihydro-1H-benz[ $f]$ indole-2-yl) methyl (compound 23) led to a loss or decrease of antiaggregation activity. Two quinazoline- and one benzothiazole-substituted aromatic thiosulfonic acid esters (compounds 22, 24, 25) also did not demonstrate antiaggregation abilities.

Among the diesters, S, $\mathrm{S}^{1}$-(1,4-dioxo-1,4-dihydro-naphthalene-2,3di-yl)-bis(4-acetylaminobenzenethiosulfonate) (compound 26) revealed significant anti-platelet activity. Interestingly, the deacylation of 4-acetylaminobenzene fragment (compound 27) led to a loss of antiaggregation effect. A similar tendency was observed for the following two thiosulfonate derivatives: diester -bis(4acetylaminobenzenethiosulfonate) (compound 28) inhibited ADP-dependent aggregation, whereas diester -bis(4-aminobenzenethiosulfonate) (compound 29) did not exhibit antiaggregation ability. It should be noted that the compounds 28 and 29 are inherently derivatives of the biologically active compound 20, which contains a free amino group, acylation of which (compound 17), conversely, led to a loss of antiaggregation activity. For the following thiosulfoacid diesters (compounds 30, 31, 32, 33), there were no significant ADP-dependent aggregation inhibitory effects observed.

Thus, the results of screening test on the study of the antiaggregation effect of non-protein low molecular weight compounds, namely thiosulfonic acid derivatives, revealed four structures of thiosulfonate with diiodomethyl- (compound 5) and quinone moieties (compounds 16, 20, 26), which inhibited ADP-dependent aggregation by $70-100 \%$ at a concentration of $50 \mu \mathrm{M}$. In our opinion, these thiosulfo-derivatives can be considered as promising antiplatelet agents that prompted us to further research their antiaggregation effects.

The next step of our work was to study the inhibitory effect of these compounds on ADP-dependent platelet aggregation in terms of their different concentrations in the incubation medium. It was found that the studied compounds affect ADPdependent aggregation in a dose-dependent manner (Fig. 1).

The compounds 5 and 20 completely inhibited ADP-dependent platelet aggregation at a concentration of $75 \mu \mathrm{M}$. The concentration the led to a gradual decline in decrease inhibitory effect, which ceased at a concentration of 5-10 $\mu \mathrm{M}$. The $\mathrm{IC}_{50}$ values for these compounds were very close and were around $25 \mu \mathrm{M}$.
The compounds 16 and 26 appeared more effective: they completely inhibited the ADP-dependent aggregation at the concentration of $30 \mu \mathrm{M}$. This effect vanished only approaching nanomolar concentrations. The $\mathrm{IC}_{50}$ values for these compounds were 10 and $8 \mu \mathrm{M}$, respectively.

We also studied the effect of these compounds on collagen-dependent platelet aggregation that may serve as a model for the assessment of the secretion of biologically active compounds from their granules. The aggregatogram, showing the response of the control PRP platelet to the addition of collagen, had the characteristic 60 -sec lag period, during which the platelet activation occurs and the release of the biologically active compounds from the granules starts. In this case it was the secondary platelet aggregation, and it started from the second phase, that is secretion. The maximum degree of aggregation in control PRP at its 2-min incubation with 1\% DMSO, in response to the addition of collagen was $64 \pm 3 \%$.

The obtained results showed that the platelet aggregation induced by collagen was also sensitive to the action of the studied compounds (Fig. 2).

Complete inhibition of collagen-dependent aggregation in the presence of the compounds 5 and 20 occurred at high concentrations: 100 and $75 \mu \mathrm{M}$, respectively. A decrease in the concentration of these compounds in PRP led to a decrease in their inhibitory effect. These compounds had similar efficacy that was evidenced by their similar $\mathrm{IC}_{50}$ values (about $60 \mu \mathrm{M})$. The inhibitory effect of the compounds 16 and 26 was already observed at concentration of 0.5$1 \mu \mathrm{M}$ and gradually increased with the increase in the concentration, reaching a maximum at $7.5 \mu \mathrm{M}$. The $\mathrm{IC}_{50}$ values for these compounds were in the range of 1.5- $2 \mu \mathrm{M}$. The obtained results showed that the lag period of collagen-induced aggregation increased proportionally to an increase in concentrations of the studied compounds that may indicate inhibition of platelet activation.

Thus, the obtained results indicate the prospects of the search for potential antiplatelet agents among derivatives of thiosulfonic acids. By analyzing the "structure-activity" relationships, potentially active chemical groups in the molecular structure, essential for the antiaggregation effect were found. The obtained data can be used as a basis for targeted synthesis of novel compounds to develop more effective antiplatelet agents.

Thus, two structural formulas of thiosulfo- derivatives were established, which exhibit high anti- 

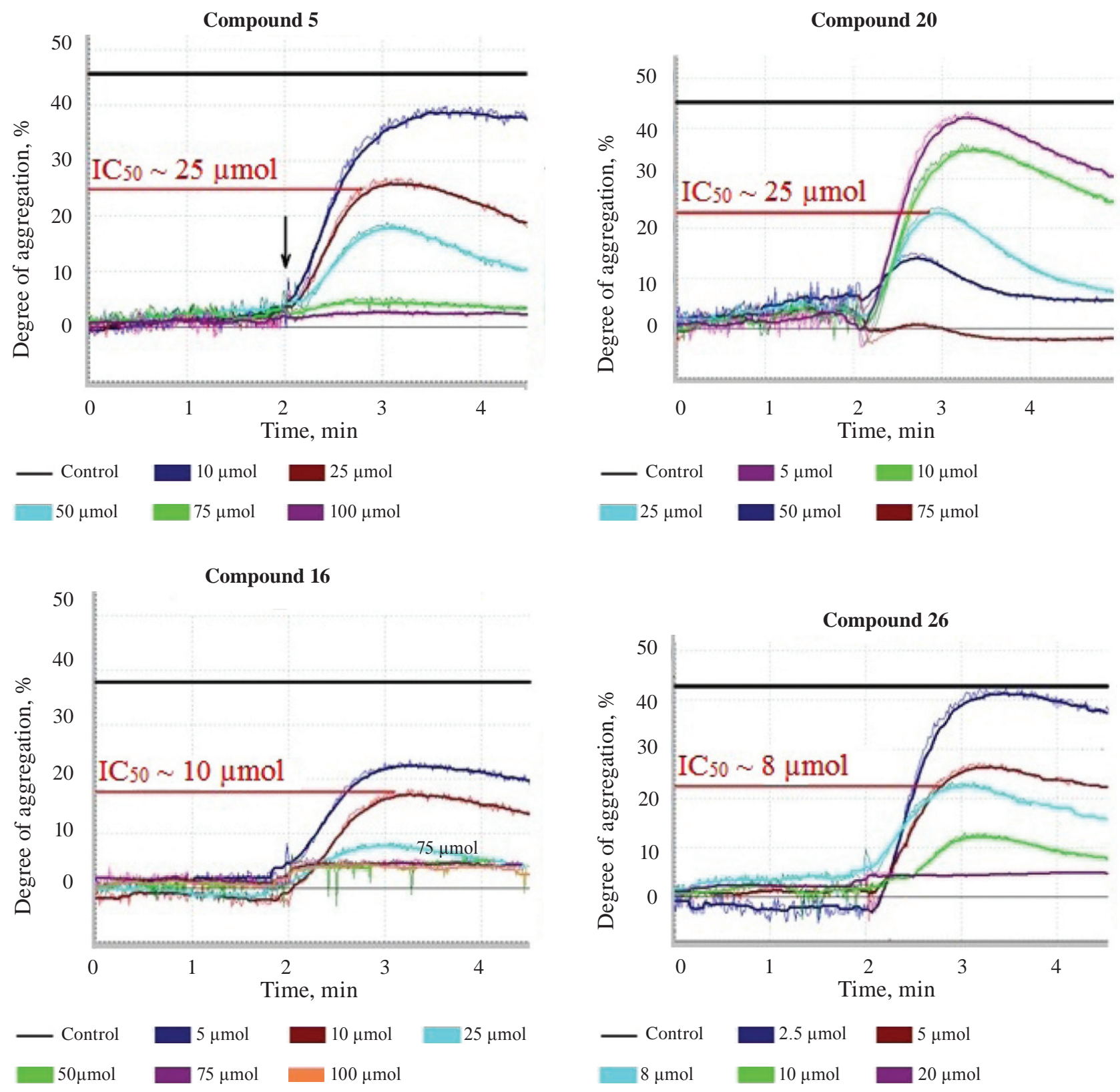

Fig. 1. ADP-dependent platelet aggregation in the presence of the studied compounds at different concentrations in the incubation medium

aggregation activities in vitro on rabbit blood PRP with the $\mathrm{IC}_{50}$ values in the range of $1-10 \mu \mathrm{M}$. The obtained data do not allow to suggest a mechanism of inhibitory effect of the studied compounds on platelet functioning and therefore, further researches are required. 
Compound 5

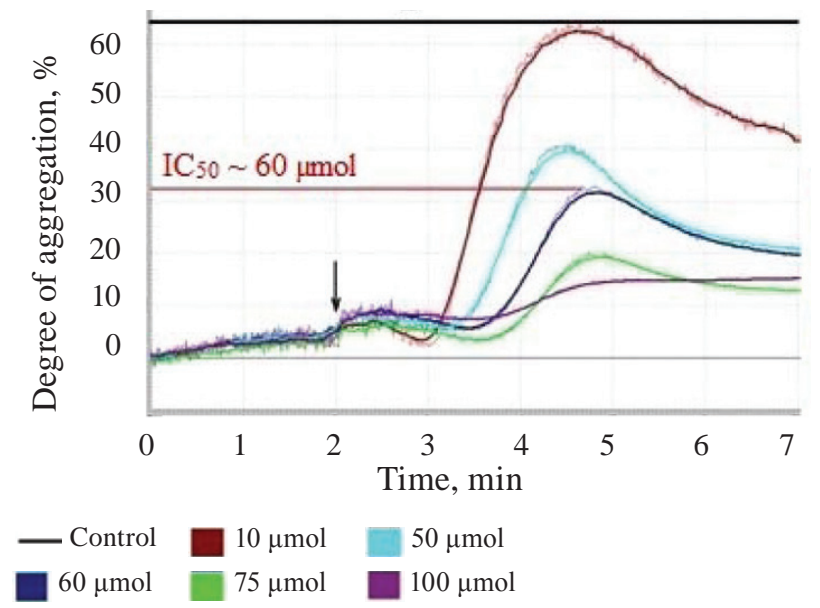

Compound 16

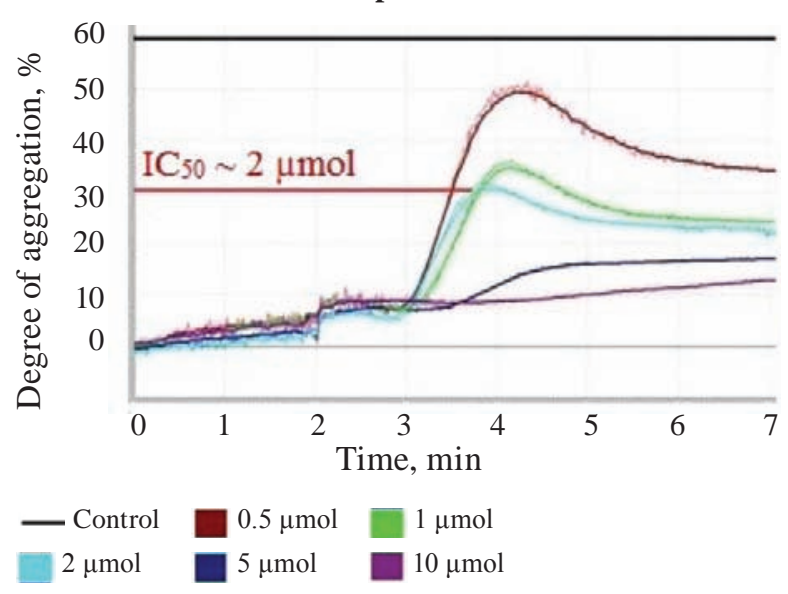

Compound 20

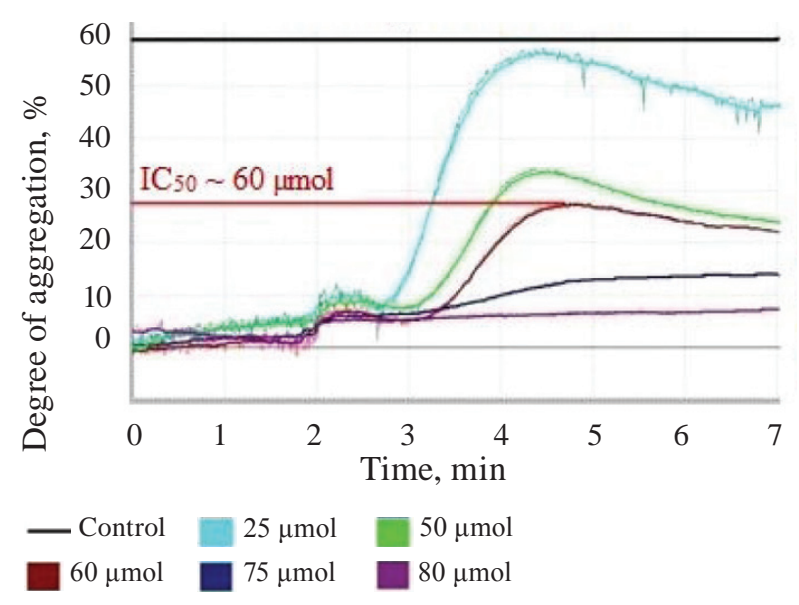

Compound 26

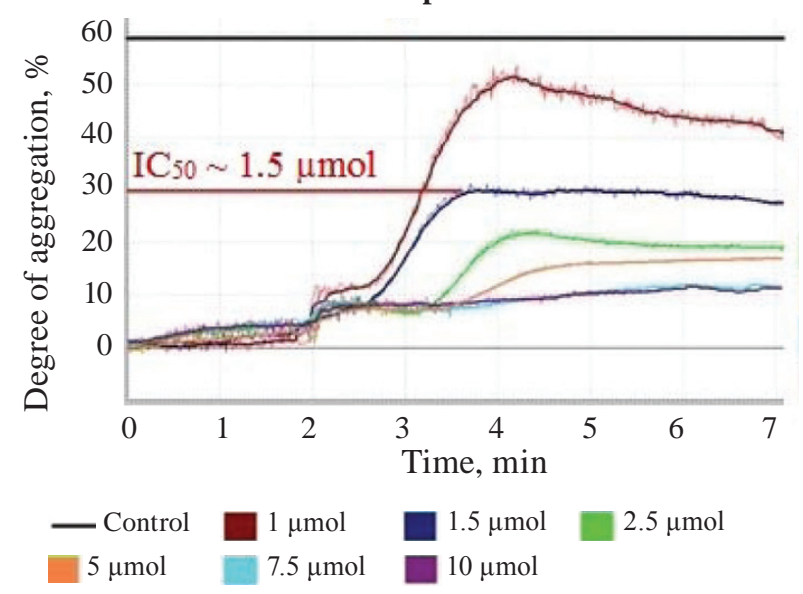

Fig. 2. Collagen-dependent platelet aggregation in the presence of the studied compounds at different concentrations in the incubation medium

\section{ПОШУК СПОЛУК 3 \\ АНТИАГРЕГАЦЙНОЮ \\ АКТИВНІСТЮ СЕРЕД S-ЕСТЕРІВ ТІОСУЛЬФОКИСЛОТ}

\section{Т. І. Галенова ${ }^{1}$, І. В. Ніколаєва ${ }^{1}$,}

А. В. Наконечна ${ }^{2}$ Х. Б. Болібрух $x^{2}$

Н. Я. Монька ${ }^{2}$ В. І. Лубенеиь ${ }^{2}$,

О. М. Савчук', В. П. Новіков ${ }^{2}$,

Л. I. Остапченко ${ }^{1}$

${ }^{1}$ ННЦ «Інститут біології», Київський національний університет імені Тараса Шевченка, Україна;

${ }^{2}$ Національний університет «Львівська політехніка», Україна;

e-mail: galenovatanya@rambler.ru

Згідно iз сучасними уявленнями гіперактивація тромбоцитарної ланки системи гемостазу може призводити до підвищення внутрішньосудинного зсідання крові та тромбоутворення. Сьогодні актуальним питанням $\epsilon$ пошук нових антитромботичних агентів, які здатні впливати на активність тромбоцитарних рецепторів, i, тим самим, регулювати процеси активації та агрегації тромбоцитів. Метою цього дослідження було вивчення впливу новосинтезованих похідних тіосульфонатів на процес агрегації тромбоцитів. Активність сполук перевірена в експериментах in vitro 3 використанням багатої на тромбоцити плазми. Внаслідок проведеного скринінг-тесту встановлено структурні формули чотирьох агентів, що мали високу антиагрегаційну активність. Ці сполуки дозозалежним чином інгібували ADPта колагеніндуковану агрегацію тромбоцитів. Показано, що із досліджених сполук дві $\epsilon$ найефективними інгібіторами агрегації, 
спричиненої ADP ( $\mathrm{IC}_{50} \sim 8-10$ мкM), а також колагеном ( $\mathrm{IC}_{50} \sim 1,5-2,0$ мкM).

К л юч о в і с ло в а: тромбоцити, агрегація, похідні тіосульфокислот, антагоністи ADPрецепторів, антитромботичні агенти.

\section{ПОИСК СОЕДИНЕНИЙ С АНТИАГРЕГАЦИОННОЙ АКТИВНОСТЬЮ СРЕДИ S-ЭФИРОВ ТИОСУЛЬФОКИСЛОТ}

\author{
Т. И. Галенова ${ }^{1}$, И. В. Николаева ${ }^{1}$, \\ А. В. Наконечна ${ }^{2}$ К. Б. Болибрух ${ }^{2}$, \\ Н. Я. Монька ${ }^{2}$ В. И. Лубеней, А. Н. Савчук ${ }^{1}$, \\ В. П. Новиков ${ }^{2}$, Л. И. Остапченко
${ }^{1}$ УНЦ «Институт биологии», Киевский национальный университет имени Тараса Шевченко, Украина;
${ }^{2}$ Национальный университет «Львовская политехника», Украина; e-mail: galenovatanya@rambler.ru

В соответствии с современными представлениями, гиперактивация тромбоцитарного звена системы гемостаза может приводить к повышению внутрисосудистого свертывания крови и тромбообразованию. Сегодня актуальным вопросом является поиск новых антитромботических агентов, которые способны влиять на активность тромбоцитарных рецепторов, и, тем самым, регулировать процессы активации и агрегации тромбоцитов. Целью данного исследования было изучение влияния новосинтезированных производных тиосульфонатов на процесс агрегации тромбоцитов. Активность соединений была проверена в экспериментах in vitro с использованием богатой на тромбоциты плазмы. В результате проведенного скринингтеста установлены структурные формулы четырех агентов с высокой антиагрегационной активностью. Эти соединения дозозависимым образом ингибировали ADP- и коллагениндуцированную агрегацию тромбоцитов. Показано, что из исследованых соединений два являются наиболее эффективными ингибиторами агрегации, вызванной $\mathrm{ADP}\left(\mathrm{IC}_{50} \sim 8-10\right.$ мкM), а также коллагеном ( $\mathrm{IC}_{50} \sim 1,5-2,0$ мкM).

К л юче вы е с ло в а: тромбоциты, агрегация, производные тиосульфокислот, антагонисты ADP-рецепторов, антитромботические агенты.

\section{References}

1. ISTH Steering Committee for World Thrombosis Day. Thrombosis: a major contributor to global disease burden. J. Htromb. Haemost. 2014;1:1580-1590.

2. Furie B., Furie B. C. Mechanisms of thrombus formation. N. Engl. J. Med. 2008;359(9):938-949.

3. Munnix I. C., Cosemans J. M., Auger J. M., Heemskerk J. W. Platelet response heterogeneity in thrombus formation. Thromb. Haemost. 2009;102(6):1149-1156.

4. Robless P. A., Okonko D., Lintott P., Mansfield A. O., Mikhailidis D. P., Stansby G. P. Increased platelet aggregation and activation in peripheral arterial disease. Eur. J. Vasc. Endovasc. Surg. 2003;25(1):16-22.

5. Broos K., Feys H. B., De Meyer S. F., Vanhoorelbeke K., Deckmyn H. Platelets at work in primary hemostasis. Blood Rev. 2011;25(4):155-167.

6. Wagner D. D., Burger P. C. Platelets in inflammation and thrombosis. Arterioscler. Thromb. Vasc. Biol. 2003;23(12):2131-2137.

7. Freedman J. E. Molecular regulation of platelet-dependent thrombosis. Circulation. 2005;112(17):2725-2734.

8. Ji X., Hou M. Novel agents for anti-platelet therapy. J. Hematol. Oncol. 2011;4:44.

9. Bolibrukh K., Polovkovych S., Khoumeri O., Halenova T., Nikolaeva I., Savchuk O., Terme T., Vanelle P., Lubenets V., Novikov V. Synthesis and anti-platelet activity of thiosulfonate derivatives containing a quinone moiety. Sci. Pharm. 2015;83:221-231.

10. Block E., Shu-Hai Zhao. Allium chemistry: simple synthesis of antithrombotic cepaenes from onion and deoxycepaenes from oil of shallot by reaction 1-propenethiolate with sulfonyl halides. J. Org. Chem. 1992;57(22):5815-5817.

11. Martelli A., Testai L., Marino A., Breschi M. C., Da Settimo F., Calderone V. Hydrogen sulphide: biopharmacological roles in the cardiovascular system and harmaceutical perspectives. Curr. Med. Chem. 2012;19(20):3325-3336.

12. Takada N., Watanabe M., Suenaga K., Yamada K., Kita M., Uemura D. Isolation and structures of hedathiosulfonic acids $\mathrm{A}$ and B, novel thiosulfonic acids from the deep-sea urchin Echinocardium cordatum. Tetrahedron Lett. 2001;42:6557-6560. 
13. Lubenets V., Karpenko O., Ponomarenko M., Zahoriy G., Krychkovska A., Novikov V. Development of new antimicrobial compositions of thiosulfonate structure. Chem. Chem. Technol. 2013;7:119-124.

14. Mon'ka N. Y., Vasylyuk S. V., Lubenets V. I., Kovalenko S. I., Novikov V. P. Reaction of 4-chloroquinazoline with arenesulfonothioic acid salts. Russ. J. Org. Chem. 2013;49(12):18571858.

15. Asmis L., Tanner F. C., Sudano I., Lüscher T. F., Camici G. G. DMSO inhibits human platelet activation through cyclooxygenase-1 inhibition. A novel agent for drug eluting stents? Biochem. Biophys. Res. Commun. 2010;391(4):1629-1633.

16. Floyd C. N., Passacquale G., Ferro A. Comparative pharmacokinetics and pharmacodynamics of platelet adenosine diphosphate receptor antagonists and their clinical implications. Clin. Pharmacokinet. 2012;51(7):429-442.

17. Alexopoulos D. P2Y12 receptor inhibitors in acute coronary syndromes: from the research laboratory to the clinic and vice versa. Cardiology. 2014;127(4):211-219.

18. MacDonald J. A., Marchand M. E., Langler R. F. Improving upon the in vitro biological activity of antithrombotic disulfides. Blood Coagul. Fibrinolysis. 2004;15(6):447-450.

19. MacDonald J. A. Langler R. F. Structureactivity relationships for selected sulfur-rich antithrombotic compounds. Biochem. Biophys. Res. Commun. 2010;273:421-424.

Received 03.06.2015 